\title{
A New Social Contract: Rethinking the Role of the State Towards Post- 2015 Development Agenda
}

\author{
Yeni Bir Toplumsal Sözleşmeye Doğru: 2015 Sonrası Kalkınma Gündeminde Devletin \\ Rolünü Yeniden Düşünmek
}

Meneviş UZBAY PIRILI' ${ }^{1}$ Mustafa PIRILI

\begin{abstract}
As the target date for achieving the Millennium Development Goals ends in 2015 a broad consultative process headed by UN is being conducted all around the world in order to formulate new goals/targets within the broader framework of sustainable human development. The main argument of this paper is founded on the major fault line in neoliberal thinking with its belief in self regulating markets and its anti-state rhetoric whose harmful consequences have been exposed by the current economic crisis. We argue that there is a need for reconsidering the potential for the role of the modern State which is adapted to the challenges of the 21st century. We suggest that the concept of social contract in discussing the role of the State may be very helpful as it broadens the concern for development beyond the State versus Economy dichotomy. The essence of any social contract is a consensus among the members of a society with regards the regulation of collective life which is grounded upon the utmost values. As such it legitimizes the roles of the State in promoting these goals, and also the structures of interaction between the State and the civil society. Therefore we argue that, the concept of social contract may provide a basic framework into the post-Millenium debates which seek to construct a new global development agenda based upon globally agreed values and goals.
\end{abstract}

Keywords: Social contract, welfare state; sustainable development; millenium development goals; economic liberalism

\section{INTRODUCTION}

As the target date for achieving the Millennium Development Goals ends in 2015, the international development community has already started discussions over the post 2015 development agenda. A broad consultative process is being conducted all around the world in order to formulate new goals and targets within the broader framework of an inclusive, equitable and sustainable development. The main argument of this paper is founded on the major fault line in neoliberal thinking with its unquestioned belief in self regulating markets. The drastically harmful consequences of this myth and its twin minimal or anti-state rhetoric have been exposed by the current

\begin{abstract}
ÖZET
Binyıl kalkınma hedefleri için belirlenen son tarih olan 2015 yılına yaklaşıldıkça BM önderliğinde uluslararası düzeyde çok çeşitli toplantı ve zirveler yapılmaktadır. Bu toplantıların amacı bir yandan geçmiş on beş yılın değerlendirmesini yapmak diğer yandan sürdürülebilir kalkınma genel çerçevesi içinde 2015 sonrası genel kalkınma hedeflerini belirlemektir. Bu makalenin temel argümanı; son büyük iktisadi krizin gösterdiği gibi, serbest piyasaların etkin işlediği ve minimum devlet tezleri üzerine kurulu neoliberal görüşün ciddi yetersizlikleri ve eleştirisi üzerine odaklanarak, devletin rolünün yeniden tanımlanmasının gerekliliğidir. Bu kapsamda 21 yüzyıldaki ciddi tehditlerle mücadele edebilmek için modern devletin rolünün neler olabileceği tartışımaktadır. Toplumların kalkınmasında devletin rolünün ne olabileceğine ilişkin tartışmada, tartışmada, devletpiyasa ikileminin dar çerçevesini aşmamıza yardımcı olabilecek olan, toplumsal "sözleşme" kavramını temel almaktayız. Her toplumsal sözleşme toplumsal hayatın nasıl düzenleneceğine ve yönetileceğine ilişkin toplumdaki öznelerin konsensüsünü içerir ve o toplamca benimsenmiş temel değerler ve hedefler üzerine kuruludur. Bu temel değerlerin ve hedeflerin gerçekleşmesi doğrultusunda gerek devletin rolünü gerekse devlet-sivil toplum arasındaki ilişkiler ile hak ve yükümlülükleri tanımlar. Buna bağlı olarak toplumsal sözleşme kavramının küresel olarak benimsenmiş değer ve hedeflere dayalı 2015 sonrası kalkınma gündeminin oluşturulmasında temel bir çerçeve sağlayacağını savunuyoruz
\end{abstract}

Anahtar kelimeler: Toplumsal sözleşme, refah devleti, Sürdürülebilir kalkınma, bin yıl kalkınma hedefleri, iktisadi liberalizm

financial and economic crisis and the necessity for governments to make major interventions in order to limit a spiralling meltdown of the economy. We argue that there is a need for reconsidering the potential for the role of the modern State which is adapted to the global human and environmental challenges of the 21 st century for a sustainable development

We suggest that the concept of social contract in discussing the role of the State may be very helpful as it broadens the concern for development beyond the State versus Economy dichotomy. The essence of any social contract is a binding agreement or consensus among the members of a society with regards the regulation of collective life which is grounded 
upon the utmost values and goals of that society as a whole. As such it legitimizes not only the roles and the authority of the State in promoting these goals, but also the processes and structures of interaction between the State and the civil society. Therefore we argue that, the concept of social contract may provide a basic framework and a powerful insight into the post-Millennium debates which seek to hammer out a new development agenda - or a new social contract - based upon globally agreed values and goals

The paper is organized in five sections. Section 2 and 3 discusses the two different perspectives on the state-economy relations: One is the perspective of economic liberalism which is based on self regulating markets and a minimal state and the other is the Welfare state approach, which asserts that the state plays an integral role in facilitating and regulating economic life to enable the working of markets. Section 4 focuses on the crisis of the welfare state. Section $\mathbf{5}$ discusses the establishment of a new social contract as a basic framework for a universal development agenda and summarizes the major arguments of the paper.

\section{The Role of the State}

Theoretical conceptualizations about the role of the state and questions about the appropriate degree of state involvement in economic affairs have generated many controversies. Much of the debate, nevertheless, takes part not as much within explanatory political theory that informs empirical research as rather within the domain of normative political economy.

Normative theory is concerned with thinking about what is to be the proper content and the degree of involvement of the state in relation to the economy and the society at large - so that best political arrangements may be decided upon. Hence, evaluation of the role of the state from a normative perspective entails at least two interrelated sets of enterprises as suggested by Pettit (Pettit, 1997 p:1)

The first and foremost is to try to look into the different perspectives not only within the limited frame of the role of the state in relation to the economy as such, but questioning the underlying values and metaphysical/ philosophical assumptions informing different models proposed on the state/society relation. Second, in the light of these fundamental values and guiding principles, taken not as peculiar to the private decision of single individuals but as socially, that is, collectively binding as a social contract, whether it may be possible to delineate the role of the state within and as part of that social contract.

We distinguish between two approaches as re- gards the historical role assigned to the state in the Western democracies since the end of the Second World War. The first, is the more recent, what we might term the contemporary approach of economic liberalism and its dominant rhetoric of the minimum state - increasingly under doubt, albeit more clandestinely than being explicitly acknowledged by governments which, in the present financial crisis, have had to massively intervene in their respective economies in order to prevent an economic meltdown. The second is the 'welfare state' where a pivotal role is assigned to the state in order to secure social solidarity. Encompassed under the term social rights, the 'welfare state' takes upon the role of ensuring the protection of not only the most vulnerable, but all against possible assaults on their ability to maintain a dignified standard of life.

\section{Minimum State : Self Regulating Society and Economic Liberalism}

In a self regulating market system the production and distribution of goods and services - the economic sphere - are coordinated by the mechanism of the market itself through the competitive price system that emerges from the voluntary transactions between buyers and sellers - of numerous people- each seeking the maximization of his or her own self-interest. The proponents of the free market system offer two related claims in order to legitimize the superiority of free markets to any other mode of coordination. One is the assumption that a self regulating free market is efficient in fostering the prosperity and material welfare of all the individuals in a society; and the other is the belief in the paramount significance of ensuring individuals' freedom - understood as the freedom of choice. It follows that the role of the state must be to enable the market system to function smoothly without interference so that its role is limited to protecting the fundamental rights of freedom and private property: this is the main argument of the advocates of the so called "minimal state". This perspective which may be called economic liberalism, owes its main premises to the economic literature of the 18th century, in A. Smith, D. Ricardo, and J.S. Mill as well as to the neoclassical economists of the 19th century and its contemporary revival in the libertarians such as Hayek, Von Mises and Nozick'.

\section{Market as a Self Regulating Civil Society}

To understand the substance of the notion of a self regulating market and its implications for the minimal state we need to look into its historical and philosophical dimensions; in other words, we need to clarify the main assumptions and the ethos - the underlying values- of economic liberalism. As Pierre 
Rosanvallon states, what is crucial to emphasise about the perspective of economic liberalism, is that the notion of the market is not simply a technical instrument that organizes economic activity through a system of competitive pricing. It involves an aspiration of a civil society which will be ideally entirely self regulating like the market (Rosanvallon, 2006, p: 148159). The representation of civil society as a market, which appears in the writings of numerous authors of the 18th century, means that it will be the market and not politics or the political authority that will be the true regulator of society. The market system with its automatic adjustments, allows for the fulfilment of material needs and interests of all the individuals in society to be realized in a coherent manner without the need for any form of hierarchical authority, subordination and power. It is no longer politics or authority that governs society but the market instead.

In other words, the idea of a self regulating civil society, fulfils the utopia of an anti-hierarchical, depersonalised, and peaceful system in which the interests of autonomous and free members of the civil society are organized.

\section{The Ethos of Liberalism: Freedom of Choice}

The understanding of economic liberalism as an utopia for a self regulating society brings us to its close connection with the liberal philosophy or liberalism especially of the English tradition ${ }^{2}$. In the contemporary attitude, there appears to be a contradiction or rather a tension between liberalism (political liberalism) and economic liberalism; Political liberalism understood as the maintenance of the rule of law and individual liberties is viewed positively whereas economic liberalism with its emphasis on the self regulating markets is rather problematic. However economic liberalism which applies to the market and political liberalism applying to the rule of law in fact belong to the same "liberal culture" (Rosanvallon, 2006, 154-155). Both share the same principles and values, with regards the conception of the human beings and the conception of a good life - the ethos- .

'Ethos' means some conception of the good life. Aristotle's most powerful insight is that in every society, moral life is based upon ethos, that is, character formation according to socially bred customs, values and habits. Every society has an ethos. One that hasn't got one would fail to be a society at all (Beiner, 1992).

So liberal society also has an ethos. Liberalism has one specific vision of the good life: that free choice of individuals is the essence of personhood ${ }^{3}$. Liberalism understood as individuals' freedom of choice is in fact based on a particular conception of the essence of what it is to be a human being; Man is (1) rational and self interested trying to further his happiness understood as utility and (2) he is free and autonomous by nature. The conception of freedom in the liberal culture assumes that we are free and self determining individual selves, unbound by prior moral ties, unbound by collective aims, capable of choosing our ends for ourselves. Not custom or tradition or inherited status, but the free choice of each individual to determine its own destiny and way of life is the source of the only moral obligations that constrain us ${ }^{4}$. Freedom therefore is understood as "negative freedom ${ }^{5 \text { " }}$ which means absence of interference. I am free in this "sense" to the degree to which no human being interferes with my activity (Berlin, 1958, p:7)

Based on this ethos, liberalism supports a distinctive way of life, characterized by the freedom every individual person to construct their own identity not being interfered by any authority (Beiner, 1992.).

The conception of individual autonomy based on freedom as non-interference, finds its most individualistic expression in the modern day libertarians such as Hayek and Nozick. According to Nozick the individual is the master of his own life, the owner of his or her person and abilities. So viewed, our rights have two sources only - our a priori ownership of our own selves and capacities and our claims on whatever resources and abilities other people have, being freely agreed to transfer to us (Nozick 1974, p: 150). This is the reason why the self regulating society - the market -with its impersonal and automatic mechanism is the best social arrangement that furthers the interests of each free individual. Friedman, in his book Free to Choose, explains this ideal of the superiority of market to all other political forms of social organizations in this manner.

"Free markets could coordinate the activity of millions of people each seeking his own interest in such a way to make everyone better off. The price system is the mechanism that fulfils this task without central direction without requiring people to speak to one another or to like one another... The price system works so well, so efficiently that we are not aware of it most of the time. (Milton and Rose Friedman, 1979, 13-14 cited in P. Rosanvallon, 2006)

\section{Neutral State: Priority of Individual Goal over Common Goals}

Therefore liberalism supports a minimal and 'neutral' state. Neutral in the sense that political decisions should be independent of any particular conception of the good life or of what gives value to life. In other words, the state should try to be neutral towards the conception of a good life for the society which 
involves furthering some common aims and goals. It follows that there is always the priority of individual goals over the common goals or common good. Furthering of any common goal by the state, would be considered as an evil which interferes with the freedom of individuals (Pettit, 1996). The role of the state is therefore limited to preserving the civil rights and private property rights of free and self interested individuals, and enable the functioning of the market: This is the minimum state which ensures the material conditions in which each free and self determining individual pursues his/r own goals ${ }^{6}$

However, it is not correct to say that the liberal state is "neutral" between the different life-choices, because it approves at the outset the liberal ethos and the particular conception of freedom as noninterference. As we argue below, the conception of freedom or of any other universal value such as "justice" or "dignity", which we all endorse are not substantive categories; their meanings vary throughout history and according to different philosophies and cultures.

\section{Welfare State : Emancipation from Market Dependence}

The welfare state ${ }^{7}$ is historically a political coalition established between the capitalists, workers, the civil society and the state. During the 1950's in North America and Europe, there was widespread acceptance of the concept of a new "social contract" as the foundation for a new political economy. The welfare consensus assigns the state a key role in the protection and promotion of economic and social well being of its citizens as a social and political priority. It fulfils this by creation of strong social safety nets, securing high if not always full employment and at the same time securing the legitimation of unions, giving organized labour more influence over wage setting, working conditions, and political priorities (Crotty, 2000). The concept of de-commodification initially elaborated by Karl Polanyi ${ }^{8}$ in his seminal work Great Transformation (Polanyi,1944) constitutes the backbone of the welfare state policies which involves the emancipation of people from market dependence

\section{De-commodification and Social Rights}

Commodification (Offe, 1984) is the dominant form of organization in capitalist societies. The factors of production - labour and capital - can be valued only if they are sold in the market and find buyers. In a precapitalist society however, very few of life's necessities were proper commodities in the sense that their survival was contingent upon selling their labour power or other assets they might have had. In a peasant economy based on feudal servitude, labour was not a commodity for sale in a labour market but was predetermined as compulsory servitude in the lord/ peasant relationship that was the prevailing power relationship sanctioned by tradition and custom. Market freedom is diabolical, however; a freedom whose hidden face is market dependence where there is always the danger of redundancy and unemployment due to competition or the competitive privilege of a commodity against others and where the level of wages are determined by the variable ratio between supply and demand. Market dependence means not only that survival outside the market is barely possible but the per durance of a constant threat because in a system of commodification it is never certain that what is offered for sale can always find a buyer ${ }^{9}$.

De-commodification: The concept of de-commodification constitute the backbone in the formulation of the redistributive social policies of the welfare state. It means securing a service or income as a citizenship right so that every person can maintain a livelihood regardless of their market capacity, in other words, without reliance on the market but by virtue of a right accorded to her/him as a member of society. The forms of de-commodification include free health care and education, old age pensions, income maintenance for the ill or disabled, and unemployment benefits. What is important to underscore here is that what is regarded as a necessity for a dignified life is protected from the vagaries and uncertainties of the market by being offered universally and equally to all as a social right.

Social rights are universal rights like the civil and political rights, protected by law so that they are inviolable and they are granted on the basis of citizenship rather than depending on market performance or charity. In this sense social rights entail decommodification of the status of individuals vis a vis the market. In his pioneering work on welfare states, T.H. Marshall's states that "The welfare state is the principal mechanism by which social citizenship is conferred, whereby "social rights" are elevated in importance" (Marshall, 2006, 54-56) Therefore the major role of the welfare state is emancipation of people from market dependency ${ }^{10}$. Citizens are emancipated from the market in the sense that they can uphold a socially acceptable standard of living independent of market participation (Gosta E. Andersen, 1990)

\section{The Ethos of the Welfare Contract: Social Solidarity}

How shall we address the question of why the state assumed such a role, which, for instance, is quite different than that of the minimum state of economic liberalism? This brings us to addressing the ethos of 
the welfare state paradigm. The moral principles that define what a good life is.

The underlying principle of the welfare ethos is collective solidarity and the social bond promoted by the ethos of care for the vulnerable. Solidarity in general, is unity that produces or is based on shared interests, objectives, and principles. It refers to the ties in a society that bind people together as existing interdependently and together within a whole. The welfare contract, in its foregrounding of "social citizenship" acknowledges the mutual responsibility and indebtedness between the society and the individual because it is informed by the interdependence of social life. The concept of "social citizenship", rather than the self seeking autonomous individual of free market liberalism, reveals the ethos of solidarity and mutual responsibility underlining the differential understanding of what the meaning of an individual human being is ${ }^{11}$. It is in this sense that T.H. Marshall focuses on the central role of "social citizenship and asserts that it constitutes the core idea of a welfare state .

It is the mutualisation or sharing of common social risks generated by the free market system and the quest for addressing them collectively through the welfare state's redistributive policies that generated social solidarity in the welfare society. Social rights are rooted in a kind of social debt to the citizen. There is this civic or citizenship dimension of social solidarity. Hence the conception of justice, in welfare paradigm is based on distributive justice ${ }^{12}$. Distributive or corrective justice aims at (economic) "real" equality and is based on the principle of redistribution between the rich and the poor corresponding to the maxim "to each according to his needs" (Rosanvallon, 2000) .

The underlying principles and values of social debt, solidarity and collective responsibility of the welfare state are quite different, almost the contrary to those of the liberal conception of society as a collection of autonomous/free individuals who are indifferent to each other. In the welfare paradigm, society is viewed as a community in the sense that there is a common fate, for good or ill, that is shared by everyone and, therefore, should be addressed collectively. The idea behind the welfare state is that the entire society at some stage throughout their lives, are under the threat of common risks generated by the market, such as unemployment, sickness, old age etc. because of which there is need for a collective agent - the welfare state in this case- acting on behalf of them to address these common risks and vulnerabilities.

\section{Crisis of the Welfare Contract : The Loss of Solidarity}

The welfare state is ill. It has been in crisis since the 1970s. Its crisis is not only confined to the financial but a philosophical and a moral crisis as well.

The financial crisis is mainly due to sluggish growth since the 1980's, accompanied by long lasting unemployment and the increasing budget share of social security expenditures. The total sum of health expenses, on the other hand, have also reached a very high level within the EU economies, absorbing around 7 percent of the GDP. If medical consumption continues to advance with an increasingly high ratio of an aging population, it is expected to gradually devour available resources for other functions like education or research (Rosanvallon, 2004). The financial crisis of the welfare state has brought measures to cut on most of the welfare expenditures and privatization of many of the hitherto publicly owned services and amenities including transport, energy, and to some degree education and health care.

The crisis of the welfare contract at the moral level is more complex and it constitutes the main challenge for the future of a new welfare contract. The moral crisis involves questioning - often in disparaging rhetoric, like the so called "nanny state"- the traditional redistributive mechanisms of the 1960's which produced confidence in social solidarity and safety against unforeseen poverty, sickness, ailing health or disability that have been for some time now, disintegrating rapidly.

The social solidarity and collectivity generated within the welfare paradigm was based on sharing common social risks and the quest for addressing them collectively through the welfare state's redistributive policies. Therefore, the welfare state itself was acting on behalf of a collective will of redistribution and social welfare. It is in this sense that the welfare state of the 1960's was acting like a big social insurance establishment which compensated for risks whenever they occurred ${ }^{13}$. It is this specific mechanism which is disintegrating today. The reasons may be summarized as follows:

1. The Scale of the Risks Have Changed: The notion of risks and threats is certainly still relevant today but the nature and the scale of the risks have changed entirely. The increasing problems to day are the catastrophic risks due to severe environmental damage, possible nuclear accidents; long lasting and mass unemployment, inequality increasing world wide, and the global financial - economic crisis haunting the entire world populations. In the context of these contemporary risks, the vision of social rights as compensations 
for temporary risks (illness, short term unemployment etc.) seem to be inappropriate. It is not any more possible to address these risks unequivocally within the insurance logic of the traditional welfare state.

2. Social Disintegration The traditional welfare contract owed its rationality and its vision of a society as a uniform whole to the Enlightenment. It was based on stipulating the main social differentiation and conflict as that between the capitalist and the working classes which were regarded as undifferentiated unities within themselves. The welfare state both represented this idea of an organically integrated society and took upon itself the role of realising its common objectives. "Hence the implicit principle of solidarity and social tie of the welfare state was based on the idea that the risks were equally distributed and largely unpredictable within this uniform society" (Rosanvallon, 2000, p: 34) In other words, the aim of social solidarity as constituting the basis of the collective bond was founded on the assumption of common risks that concerned and was prone to encounter everyone equally. Today, however, we can hardly describe the highly complex social texture of the societies within which we live by uniformity, where social identity is diversified and often defined in terms of ethnic, cultural and sexual differences. Parallel to the differentiated social identities people tend to assume within the same society, the risks they expect to encounter also differ from others' in relation to whom they recognise their difference rather than a common destiny.

3. The Top-Down Solidarity: In the traditional welfare state, social solidarity was embedded in a topdown statist structure. The state, acting in the name of the society, as the very organ that embodies their representation, is the principle agent that is expected to organise and put into effect the collective targets, services and the social security benefits. The participation of civil society in this process tends to be rather passive involving not much more than agreeing to pay tax and thereby share the cost of the state's expenditure for protection against common risks and vulnerabilities. When social solidarity finds expression in an all-powerful top - down state legislation and execution, the solution to all the problems and risks are also expected to be solved by the state and demanded from the state alone, with marginal active participation by civil society and its organisations.

In the light of the difficulties and the changing global circumstances we tried to outline above, not only economic but in so many other cultural respects as well, it may not come as a surprise to suggest how difficult it will be, today, to conceive a social solidarity constructed along the same lines with the traditional role assigned to the welfare state.

Around the 1980s, following the disintegration and the crisis of the welfare contract, the self regulating market economy paradigm - the neoliberal contract - finally came to be accepted as the unequivocal corrective to the ills of the period. However, the drastically harmful consequences of the unquestioned belief in unregulated markets and its twin minimal or anti-state rhetoric have been exposed by the current financial and economic crisis and the necessity for governments to make major interventions in order to limit a spiralling meltdown of the economy. Under this crisis atmosphere, there is a need to reconstruct a consensus concerning the role of the modern State and its complex relationship to a complex and differentiated civil society. In other words there is a need to build a new social contract.

\section{A New Social Contract: Rebuilding Social Solidarity and Social Bond}

The idea of the social contract ${ }^{14}$ has been familiar for centuries, since it appears in the works of classical authors such as Thomas Hobbes, John Locke, Jean-Jacques Rousseau, Immanuel Kant, and the contemporary works of J. Rawls who revived the concept of social contract in his book $A$ Theory of Justice (Rawls, 1971). Although these great writers differ in their assumptions about how humans behave, on what would lead them to consider authority legitimate and the main values and principles underlying the conception of society, their endeavour was to create a political framework, on the basis of which a stable and habitable political and social order could be constructed. Today, in 2015, our problem is similar to theirs and our questions are essentially the same: How can we change today's troubled world - "a world in turmoil and turbulence, with no shortage of painful political upheavals"- to something better? (Ban K. Moon, 2015, p: 45). The international community headed by UN is pursuing a similar endeavour. As the target date for achieving the Millennium Development Goals ends in 2015, a broad consultative process is being conducted all around the world in order to formulate new goals and targets. Within this endeavour, UN calls for a renewed global partnership and solidarity in order to construct a single and new development agenda within the broader framework of sustainable development - enabled by the integration of economic growth, social justice and environmental stewardship- (UN, 2013a; 2013b; UNDP 2012). UN High Level Panel believes that "there is a need for a paradigm shift" (UN 2013a, 7) in order to fulfil the transformative shifts envisaged in the global agenda. 
In this regard, it is necessary to redefine the hard core values and principles of the new paradigm. Moreover, the definition of the respective roles and responsibilities of the State, the civil society, as well as that of the international institutions is inevitable ${ }^{15}$.

We suggest that the concept of social contract could provide a basic framework and a powerful insight into the post-Millennium debates that seek to hammer out a new development agenda. - or a new social contract - . A social contract is a binding agreement for all the members of a society as regards the regulation of collective life grounded upon the utmost values and goals as the ethos of that society. In other words, the underlying values of any social contract legitimizes not only the roles and the authority of the State in promoting these goals, but also the processes and structures of interaction between the State and the civil society.

The important question is "how to establish such a global social contract?"16 In the quest for constructing a new social contract based on social solidarity we suggest that the following issues are worth considering:

\section{The ethos: How do we want our future to be - The hard core values}

In any normative inquiry about social life, what is indelibly implicit, if not always acknowledged, is a certain conception of the fundamental requisites of a good life -thus, a conception of a bad life as well - guiding the kind of lives we expect to have for ourselves and would like to bequeath to our children and future generations. How do we want our future to be? We are accustomed to rush into stereotypical answers in response to this question by reiterating the democratic values such as freedom, equality, justice, dignity, etc., without much thought upon their concrete life-meaning.

We say that the fruits of development should be distributed 'fairly' or 'justly' but what are the norms of 'justice'? ${ }^{17}$ To ask whether a society is just, is to ask how we attribute value to things, and according to this valuation how we treat these things. A just society values and treats and therefore distributes things in the right way. The hard question is when we ask what the right way is . The justice of the liberal market is based on utility ${ }^{18}$ and voluntary equal exchange. The exchange is said to be just, because on the one hand it conforms to natural traits of human beings and on the other hand market exchange is voluntary and is assumed to be mutually advantageous for the parties. The justice of the market is usually called commutative justice which is about the treatment of an individual in a particular transaction - it is about giving someone what he or she deserves or has a right to (Rosanvallon, 2004) So A. Smith claims that market is such a marvellous device that combines justice with self interest. Distributive justice ${ }^{19}$, on the other hand, in its modern sense calls on the state to ensure that everyone is provided with a certain minimum level of material means necessary to maintain a dignified life (S. Fleischacker, 2005). This ethical principle was what constituted the underlying ethos of the traditional Welfare State,

Take another controversial concept such as 'freedom'; what do we understand by that? We argued in this paper that liberalism has one particular vision of freedom, defined negatively as non-interference. Hence 'a good life', namely, that free choice of autonomous individuals is the essence of personhood. It follows that the role of the state is also defined negatively in terms of its non-interference as a minimal state. The practical policy implications of the liberal conception of freedom is that, if non-interference is the standard with which to evaluate public policies then the effect would be "not to require much in the way of distribution: not to require much in the way of what we intuitively describe as distributive justice". (Pettit, 2008, p :403). The neutrality of the state in the liberal conception means that it should not further common goals (social good) such as distributive justice or MDG's so as not to interfere with the freedom of every individual to pursue their own aims. In fact the dichotomy between individual goals and common goals constitutes the main dispute between liberal culture and its critics .

Any social contract should first involve inquiring about the uppermost values as the guiding principles of social life on which political arrangements could be founded. An ethos, however is not made up of abstract concepts, formulated in binary opposites like freedom vs. oppression, equality vs. Inequality, etc., but lies in the detail and concreteness of 'how'.

\section{Social Solidarity and Social Bond}

The ethos of the neoliberal contract leaves no room for social solidarity and for social/common aims and responsibilities. The social bond in a market society is essentially economical: it is the market itself: the voluntary exchange relations operating like an invisible hand and linking each self-interested autonomous individual temporarily in a market transaction. A market relation is antagonistic-each seeking to maximize her or his own gain and minimize her or his cost against the other where related parties are competing against each other in pursuit of their own self-interest and so is in contrast, for example, to the social bond of the welfare state, involving the com- 
mon goal of social solidarity based on redistribution.

In the liberal conception of the 'self-seeking natural individual', society seems to be no more than a collection of autonomous individuals; the liberal individualist conception of citizenship confines the responsibility of individuals towards their society to merely paying taxes, obeying the law and engage in business. However, no society is a haphazard collection of individuals. What makes a crowd on the street or a number of people waiting for the train at a station, members of a particular society is that their behaviour towards each other always assumes certain norms, a certain knowledge of 'right' and 'wrong' concerning what they expect and not expect from themselves and others in relation to each other. In every society, for example, there are norms of respect for each other for whose observance every individual is held responsible. An individual, to the measure that $\mathrm{s} / \mathrm{he}$ is a member of a certain society, is not merely an individual of a natural species but a social individual as well as being a private individual. The differentiation between the public and the private, their limits and relation to each other itself is not given by nature but socially defined.

We may say that the liberal ethos, its conception of society, of freedom as non-intervention, is not good enough to generate the social bond and solidarity which is essential to address the major global challenges and to promote our collective vision of sustainable development. On the contrary, the liberal ethos and the neoliberal ideology based on competition have undermined the sense of community and the inclination of people towards solidarity. As Ronald Beiner tells us :

"the minimum notion of a community required to cope with these grave political realities is the sense that our fate, for good or ill, is a shared one, from which no one can sensibly retreat into a private domain of either pleasures of consumption or burdens of conscience... If our world succumbs to nuclear or ecological catastrophe, we all suffer the same fate; if injustice, inequality, and political oppression run rampant in our world, we are all diminished as human beings; if the absence of a common culture leads to a new, post literate barbarism, we are all the worse for it" (Beiner, 1992, pp: 34-35)

We also argued that, social solidarity is one of the fundamental principles of the ethos of the traditional welfare contract and yet its mechanism of creating the social bond has been disintegrating. Solidarity in the welfare contract was based on the sharing of social risks so that the welfare state was acting like a big social insurance establishment which compensated for risks whenever they occurred. It is this specific mechanism which used to generate solidarity that is disintegrating today

New Perspectives on Freedom, Equality and Citizenship

The two leading strands of arguments ${ }^{20}$ in response to the liberal culture are Communitarian critics and the New Republican School. They argue that a new emphasis on public morality, on common goods and individual obligations is the key to renewing or revising social citizenship and social solidarity. The writers from the new republican tradition, distinguish their concept of freedom from the liberal understanding of non-interference, arguing that, even without interference, liberty may be lost. Against individual freedom as non-interference, they offer the concept of political freedom as non-domination and non-arbitration. (Viroli, 2002; Pettit, 2012). People are free, according to republican conception, when no one has the $c a-$ pacity to dominate and interfere arbitrary sway over them. Domination means living at the mercy of the will of another agent, even if that agent never moves against you: it gives rise to fear and deference ${ }^{21}$. Viroli explains domination from the angle of "fear" in the sense that while interference means to limit an action, domination and hence subjugation creates fear due to the arbitrary and unpredictable nature of domination (Viroli 2003, pp: 36-37). Freedom as non-domination is supported by the new republican school in response to the shortcomings of the liberal idea of freedom that is relatively indifferent to deeply embedded inequalities as a result of unbalanced power relations especially in non-political places such as the work place, the household and the society at large. The republican ideal is "concerned with the existence in social relations of unchecked discretionary power, which induces dependency and the inability simply to pursue one's own projects and interests without the fear that others could interfere if they happen to disapprove" (Swan, 2012, p: 435)

The republican ideal has important implications for distributive justice, equality and fight against poverty. The principle of republican equality guarantees everyone a level of capability minimally necessary for avoiding domination and living as a free citizen. (Swan, 454). Commitment to the ideal of freedom as non-domination leads to a commitment to redistributive policies aiming at economic independence (Pettit, 1997, p: 159).

The main political strategies against arbitrary domination consists of the rule of law, constitutional provision and the establishment of relevant institutions to protect and further the political freedom of the citizens. Redistributive schemes and provision of 
basic requirements by the State are supported as a means to secure economic independence which protects less advantaged people against various forms of assault, exploitation and consequently, domination. Skinner argues that for institutions to work and for laws to be effective, the norms of citizenship and civic bonds should be strengthened; the citizens, besides their rights should also assume social obligations with regards the protection and support of the rule of law that furthers freedom as non-domination (Skinner, 1998)

\section{CONCLUSION}

The new global awareness of our common human destiny bring about new social, political, and cultural confrontations in order to overcome and manage the challenge of 21 th century. Humankind faces the same global challenges; providing an enabling environment to build inclusive and peaceful societies, ensure social cohesion and respect for the rule of law and addressing the risks of climate change and ecological damages (Ban K. Moon, 2014, p: 15). It is through this perception of our common destiny that we need to commit to work together to promote sustained and inclusive economic growth, social development and environmental protection and thereby to benefit all ( UNCSD, 2012).

The concept of social contract may provide a basic framework and a powerful insight in to the construction of a new global development agenda that envisages a transformative shift towards sustainable human development for two significant reasons. First, social contract, may be very helpful in discussing the role of the State as it broadens the concern for development beyond the State versus economy dichotomy. One important point to emphasize in this regard is that the framework of social contract moves beyond the limits of the concept of governance, understood as the processes of interaction between the State and the society (UNCTAD, 2009). Although the concept of "global governance" ${ }^{\prime 22}$ which simply means, the man- agement of global processes though the complex of formal and informal institutions, mechanisms, relationships, may provide useful insight into the design of appropriate global institutions, it does not carry the political vigour and coherence of the social contract concept. Second, the design of a single global development agenda within the frame work of a new social contract will strengthen the political will for a new spirit of global solidarity and partnership in fulfilling the transformative shifts envisaged by UN.

Reconstruction of a new social contract implies a redefinition and assessment of its core values and principles. We need a common understanding and interpretation of the utmost values such as freedom, justice, equality ${ }^{23}$. The liberal conceptions are relatively indifferent to inequalities, distributive justice and social solidarity. However, the contemporary contributions of political philosophy around the different conceptions of freedom and justice may provide valuable insight into the discussions and the definition of the core values of a new social contract. As some writers suggest, there is an affinity between the republican ideal of freedom as non-domination as a fundamental political value, and Amartya Sen's capabilities approach which inspired the UN's sustainable human development paradigm and the Human Development Index ${ }^{24}$. According to A. Sen the real freedom of people is their freedom to achieve well being which is principally a matter of the capabilities and entitlements they are feasibly able to achieve (Sen, 1992). Indeed, various forms of freedom proposed in the Human Development Report 2000 of UNDP ${ }^{25}$ share a similar spirit of freedom as non-domination. The redefinition of the core values also raises the question of a new political culture. A new practice of solidarity may emerge from the strengthening of the civic bonds and citizenship emphasizing social and political responsibilities of citizens, besides their rights, and their vital part to play in the pursuit of collective well being. 


\section{END NOTES}

1. For a comprehensive study on the works of liberal philosophers refer to Goodin and Pettit (2007)

2. English liberal tradition emerged during the 17 th and the18th centuries. What ever their differences, J. Lock, D. Hume, A. Smith and J.S. Mill belong to this intellectual tradition. (Rosanvallon, 2006)

3. For a comprehensive argument on the ethos of liberalism see Ronald Beiner (1992) .

4. The rational self interested human being is the so called homo economicus which dates back to the writings of utilitarian philosophers of the 19th century. Bentham says, "We are all governed by the feelings of pain and pleasure. They are our sovereign masters. They govern us in everything we do and also determine what we ought to do. The standard of right and wrong is fastened to their throne" (Bentham, 1963, pp: 24-25); Jevons, (1957)

5. İsaiah Berlin (1958), explains the dichotomy between the positive and negative conceptions of freedom. I am negatively free Berlin says, "to the degree that no human being interferes with my activity," I am positively free to the extent that I achieve "self mastery with its suggestion of a man divided against himself" (Berlin,1958, pp.7,19)

6. Nozick, criticized the tax collecting by the welfare state for the aim of redistribution, and argues that government must be equal between its citizens... people are entitled to keep the money they make, if the fruits of their labour are not at their disposal but are treated instead as part of a common pool of public wealth, this is definitely unfair. (in Sandel 2009, p:255)

7. The concept of Welfare State, was popularized by Archbishop William Temple, author of the book Christianity and the Social Order (1942), http://islandnet.com/ theologo/temple.pdf 12.06.2013

8. Temple, uses the concept welfare state in order to contrast Britain's welfare state with the "warfare state" of Nazi Germany, For a comprehensive analysis on K. Polanyi his ethics and economics see G. Baum, 1996.

9. The market also, does not have any automatic self correcting mechanisms : so that (1) unemployed labour or any commodity that does not find favour in the market will be back to the market and/or (2) the factors left outside the market can find non-market means of survival.

10. Although de-commodification policies define the basis of welfare state, another set of policies called "recommodification" policies are also included among the functions of the welfare state. Policies are designed to secure a maximum of exchange opportunities for labour and capital, hence labour and capital that have been expelled from the market can re-enter the market (Offe, 1984 and G. E. Andersen, 1990)
11. Polanyi (in Baum, 1996) criticizes the liberal assumption as regards the promotion of material self interest being the sole motive of human beings, and states that just as we are by nature rational beings endowed by freedom; so too we are ethical beings endowed with responsibility and love for our neighbour and our community. According to him humans are social and ethical beings, ethical in the sense that they are likely to protect their community, their land on which they live in and in general what is valuable for them. He asserts that, as historical conditions change love and responsibility assume new means. In the modern society. the love of neighbour has expanded in to social solidarity and as the global society expands and becomes more interdependent every human being becomes our neighbour and love begins to generate universal social solidarity (Baum, 1996: p: 64)

12. For distributive justice as fairness and as the basis of a social contract see, John Rawls (1971). See also Fleischacker, (2005) for a detailed analysis of distribuitve justice in its modern sense.

13. The above analysis of the moral crisis of Welfare State is mainly based on Rosanvallon (2000 and 2004)

14. For a study on essentials and the history of the Social Contract Theory, see, M. Lessnoff, 1990

15. UN has announced 2015 as the year of global action for establishing a universal compact for sustainable development. During 2015 the three global summits; (1) The conference in Addis Ababa on financing of development (2) September's meeting at the United Nations to adopt sustainable development goals (SDGs), and (3) the U.N. Climate Change Conference in Paris in December, will give the international community the opportunity to chart a new era of sustainable development (Ban K. Moon, 2014)

16 . For a discussion on the quest for a new global social contract see also A. Blin and G. Marin (2012)

17. M. Sandel (2009) explains the three different approaches on justice; "One approach says justice means maximizing utility or welfare-the greatest happiness for the greatest number. The second says justice means respecting freedom of choice,. The third says justice involves cultivating virtue and reasoning about the common good", (Sandel, 2009: p: 235)

18. Utilitarian justice means maximizing utility or welfare of the society-the greatest happiness for the greatest number .

19. Samuel Fleischacker (2005) argues that guaranteeing aid to the poor is a modern idea, developed only in the last two centuries. Earlier notions of justice, including Aristotle's, were concerned with the distribution of political office, not of property. It was only in the eighteenth century, in the work of philosophers such as Adam Smith and Immanuel Kant, that justice began to be applied to the problem of poverty . 
20. The contemporary political and moral criticism of liberalism comes mainly from two schools of political philosophy: The New Republican School and The Communitarian School. Some sources for the Communitarian critique are as follows : M. Sandel, Liberalism and the Limits of Justice (Cambridge: Cambridge University Press, 1982); Michael Walzer, Spheres of Justice: A Defense of Pluralism and Equality (New York: Basic Books,1983); Alasdair Mac Intyre, After Virtue (Notre Dame, Ind.: University of Notre Dame Press, 1981); Charles Taylor, "Atomism," in Powers, Possessions, and Freedom, ed. Alkis Kontos (Toronto: University). Main writers from the New Republican School are: M. Viroli (2002) P. Pettit (1995, 1996, 2003, 2006, 2012); Q. Skinner (1998); P. Rosanvallon ( 2000, 2004 and 2006) and C. Mouffe (1992)

21 . Two examples of not being politicaly free and exposed to the domination of others may be given as: An unskilled worker due to her limited employment prospects, is vulnerable to her employer's illicit treatment; Citizens of an oppressive regime where those in power are allowed to commit violations of even the most fundamental human rights without fear of any legal accountability for their actions.

22. For discussions on global governance see Stiglitz, (2004) and FNWG (2015)

23. It is through this perception of the need for common understanding that the idea of global Commons has arisen in recent years. The idea of global commons, brings us closer to asking ourselves, collectively, what kind of global society we want or "the future we want". A general definition of global Commons includes those parts of the earth's surface beyond national jurisdiction - notably the open ocean and the living resources found there-or held in common-notably the atmosphere (International Union for Conservation of Natural Resources, 1980) However taking in to consideration of the global threats which the global community faces to day the global Commons include not only the global environment but also international security and peace, economic stability and welfare, humanitarian aid and knowledge (Stiglitz, 1995)

24. See J. M. Alexander (2008) and K. Swan, (2012) for an evaluation of the affinity between A. Sen's capabilities approach, his conception of freedom as real freedom and the republican ideal of freedom as non domination

25. UNDP supports the following freedoms, which secure human development: "Freedom from discrimination; Freedom from want; Freedom to develop and realize one's human potential: Freedom from fear; Freedom from injustice and violations of the rule of law; Freedom of speech and participation; Freedom of decent work without exploitation" (UNDP 2000, p:1)

\section{REFERENCES}

Alexander, J. M. (2008), Capabilities and Social Justice, Ashgate Publishing ltd., UK

Andersen, G. E (1990) The Three Worlds of Welfare Capitalism. UK: Blackwell Publishers Ltd.

Baum, G. (1996) Karl Polanyi, Ethics and Economics. McGill-Queens University Press.

Ban Ki-moon, (2014), "The Road to Dignity by 2030", Synthesis Report of the Secretary General on the Post 2015 Development Agenda, New York

Becker, G.S. (1976) The Economic Approach to Human Behaviour, University of Chicago.

Beiner, R. (1992) What's the Matter with Liberalism, Berkeley, University of California Press.

Bentham, J. (1963) An Introduction to the Principles of Morals and Legislations. New York: Hafner.

Berlin, I. (1958) Two Concepts of Liberty. Oxford: Clarendon Press,

Blin, A and G. Marin (2012), "The Commons and World Governance, toward a global social contract” ,Forum for a New World Governance, http://www.worldgovernance.org/IMG/pdf 862 AB GM Communs GM EN v2 oct12-2.pdf (12. 01.2015)

Crotty, J. (2000) 'Trading State-Led Prosperity for Market Led Stagnation: From the Age to Global Neoliberalism', Political Economy Research Centre, PERI. http:// www.peri.umass.edu/fileadmin/pdf/published study/ PS7.pdf (accessed 17.09 2013)

Fleischacker, S. (2005) A Short History of Distributive Justice. Harvard University Press FNWG- Forum for a New World Governance, web site http://www.worldgovernance.org/rubrique48.html?lang=en (09.02.2015)

Gooin, R.E; P.A. Pettit and T. Pogge (2007) Companion To Contemporary Politic Philosophy. Blackwell Publishing Ltd International Union for Conservation of Nature and Natural Resources (1980), World Conservation Strategy . Living Resource Conservation for Sustainable Development, Chapter 18, "The Global Commons"

Jevons, W.S. (1957) The Theory on Political Economy. New York: Kelley and Millian Inc.

Lessnoff, M. (1990) The Social Contract Theory. NY: New York Unviversity Press.

Marshall, T.H. and T. Bottomore (2006) Yurttaşlık ve Toplumsal Sinuflar. İstanbul: Bilgi University Press

Marshall, T.H. (2006) Yurttaşlik ve Toplumsal Sinıflar, in Marshall T.H \& T. Bottomore (1-50)

Mill, J.S. (1989) On Liberty. S. Colilini (Ed) Cambridge University Press 
Mouffe, C. (1992) Dimension Of Radical Democracy: Pluralism, Citizenship, Community.(Ed)UK: Verso

Nozick, R. (1974) Anarchy, State, and Utopia. New York: Basic Books.

Offe, C. (1984) Contradictions of the Welfare State. Hutchinson \& Co. Publisher

Pettit, .P (1995) The Virtual Reality of 'Homo Economicus, Monist, 78 (3)

Pettit, P. (1996) Freedom and Anti-power, Ethics 106: 576-604

Pettit, P. (1997) Republicanism: A Theory of Freedom and Government, New York: Oxford University Press

Pettit, P. (2003) 'Agency-Freedom and Option-Freedom'. Journal of Theoretical Politics 15: 387-403.

Petitt, P. (2006) 'Freedom in The Market', Politics, Philosophy \& Economics, Sage Publication 5 (2): 131-149

Pettit, P. (2008) "Republican Political Theory", in Marc Fleurbaey, Maurice Salles, and John A. Weymark (eds.), Justice. Political Liberalism, and Utilitarianism: Themes from Harsanyi and Rawls. Cambridge: Cambridge University Press. pp. 389-410

Pettit, P. (2012) "Legitimacy and Justice in Republican Perspective", Current Legal Problems Vol. 65: 59-82 Available at: http://clp.oxfordjournals.org/ (17.September.2013)

Polanyi, K. (1944) The Great Transformation. New York: Rinehart.

Rawls, J.A. (1971) Theory of Justice. Oxford: Oxford University Press.

Rosanvallon, P. (2000) The New Social Question: Rethinking the Welfare State. Princeton University Press

Rosanvallon, P. (2004) Refah Devletinin Krizi. Ankara: Dost Kitabevi.

Rosanvallon P (2006) Democracy Past And Future (Ed), Samuel Moyn, Columbi University Press.

Ronald, D. (1989) Liberal Community. California Law Review 77 (3): 479-504

Sachs, J (2015) "What Bankers Must do to Help Save the Earth", in Market Watch, http://www.marketwatch. com/story/what-bankers-must-do-to-help-save-theearth-2015-02-16?page $=1,(12.02 .2015)$
Sandel, M. (2009) What's The Right Things To Do. Canada: D\&M Publishers inc.

Sen, A. (1992) Inequality Re examined. Cambridge: Mass. Harvard University Press,

Skinner, Q. (1998) Liberty Before Liberalism. Cambridge University Press, UK.

Stiglitz, J.E. (1995), "The theory of International Public Goods and the Architecture of International Organizations", United Nations Background Papers, 7, New York

Stiglitz J.E.., (2004) "The Future of Global Governance", Initiative for Policy Dialoge Working Paper Series, University of Colombia

Swan, K. (2012), "Republican Equality", Social Theory and Practice, 38 (3): 432-454

UNCSD (2012), The Future We Want, The Rio+20 Outcome Document, UN.

UNCTAD (2009) The Least Developed Countries: The State and Development Governance. Report of United Nations Conference on Trade and Development.

UNDP (2000) Human Rights and Human Development. Human Development Report 2000 of UN. http:// hdr.undp.org/en/media/HDR 2000 EN.pdf (accessed 17.September.2013)

UNDP (2013) The Rise of the South, Human Development Report 2013 of UN. http://hdr.undp.org/en/ reports/global/hdr2013/ (17.October.2013)

United Nations, (2013a) A New Global Partnership: Eradicate Poverty And Transform Economies Through Sustainable Development, Report of UN. Available at: http:// www.post2015hlp.org/wp-content/uploads/2013/05/ UN-Report.pdf (17.10.2013)

United Nations, (2013b) Follow up of to the Outcome of Millennium Summit. Report of the Secretary General, http://www.un.org/millenniumgoals/pdf/A\%20Life $\% 20$ of\%20Dignity\%20for\%20All.pdf (17.10.2013)

Viroli, M. (2002) 'The Concept of Order and The Language of Classical Republicanism in Jean-Jacues Rousseau', The Language of Political Theory in Early Modern Europe, ed. A. Pagden Cambridge University Press, pp.159-178 